\title{
A mixed-methods study of hospital-acquired infections in Mongolia
}

\author{
B-E Ider ${ }^{1 *}$, A Clements ${ }^{1}$, J Adams ${ }^{1}$, M Whitby ${ }^{2}$, A Morton², T Muugolog ${ }^{3}$ \\ From International Conference on Prevention \& Infection Control (ICPIC 2011) \\ Geneva, Switzerland. 29 June - 2 July 2011
}

\section{Introduction / objectives}

Official reports of Mongolia indicate that hospitalacquired infections (HAI) occur in $0.01-0.05 \%$ of all hospital admissions. This is considerably lower than internationally reported rates. There have been no published HAI prevalence studies from Mongolia. We aimed to determine the first accurate estimate of HAI prevalence in two tertiary hospitals of Ulaanbaatar and to seek explanation for underreporting of HAIs in Mongolian hospitals.

\section{Methods}

In 2008, a one-day survey examined all 933 inpatients in two hospitals. Cases of HAI were diagnosed using CDC (USA) definitions. Subsequently, 87 health professionals were recruited for 55 interviews and 4 group discussions. Perceived reasons and mechanisms of underreporting were identified.

\section{Results}

Prevalence of HAI was 50/933 (5.4\%) overall HAI, 0.3\% for bloodstream infection, $1.3 \%$ for respiratory tract infection, $1.3 \%$, for urinary tract infection and $1.4 \%$, for other HAI. Among surgical patients, prevalence of surgical site infection was $3.9 \%$. Participants in the qualitative study explained that underreporting of HAI is mainly a response to punitive performance evaluation by the Ministry of Health (MoH) and penalisation of hospitals and staff by the State Inspection Agency when HAI were detected.

\section{Conclusion}

The prevalence of HAIs in two Mongolian tertiary hospitals is comparable with reports from some other developing countries. The $\mathrm{MoH}$ statistics underestimate

${ }^{1}$ School of Population Health, University of Queensland, Australia Full list of author information is available at the end of the article the true burden of HAI in Mongolia. Inclusion of the overall HAI rate in the targeted performance indicator set and the use of strict control and penalisation of hospitals with reported HAI cases are factors that have contributed to gaming, which has resulted in deliberate, extreme under-reporting of HAI cases in Mongolian hospitals.

\section{Disclosure of interest}

None declared.

\section{Author details}

${ }^{1}$ School of Population Health, University of Queensland, Australia. ${ }^{2}$ Princess Alexandra Hospital, Brisbane, Australia. ${ }^{3}$ National Center for Communicable Diseases, Ulaanbaatar, Mongolia.

Published: 29 June 2011

doi:10.1186/1753-6561-5-S6-015

Cite this article as: Ider et al: A mixed-methods study of hospitalacquired infections in Mongolia. BMC Proceedings 2011 5(Suppl 6):015.

Submit your next manuscript to BioMed Central and take full advantage of:

- Convenient online submission

- Thorough peer review

- No space constraints or color figure charges

- Immediate publication on acceptance

- Inclusion in PubMed, CAS, Scopus and Google Scholar

- Research which is freely available for redistribution
C Biomed Central

(C) 2011 Ider et al; licensee BioMed Central Ltd. This is an open access article distributed under the terms of the Creative Commons Attribution License (http://creativecommons.org/licenses/by/2.0), which permits unrestricted use, distribution, and reproduction in any medium, provided the original work is properly cited. 